\title{
Team Leadership and Trust to Assess Project Performance in Higher Education: An Empirical Study
}

\author{
Ming-Ling Chuang (Corresponding author) \\ Ancell School of Business, Western Connecticut State University \\ 181 White Street, Danbury, CT 06810, United States \\ Tel: 1-203-837-8884 E-mail: chuangm@wcsu.edu
}

\begin{abstract}
Alexandra Galli-Debicella
Ancell School of Business, Western Connecticut State University

181 White Street, Danbury, CT 06810, United States

Tel: 1-203-837-8181Ｅ-mail: gallidebicellaA@wcsu.edu

\section{Xiaoqi Han}

Ancell School of Business, Western Connecticut State University

181 White Street, Danbury, CT 06810, United States

Tel: 1-203-837-9038_E-mail: hanx@wcsu.edu
\end{abstract}

$\begin{aligned} & \text { Received: June 5, } 2021 \quad \text { Accepted: August 6, } 2021 \quad \text { Published: Oct. 1, } 2021 \\ & \text { doi:10.5296/jmr.v13i4.18883 } \quad \text { URL: https://doi.org/10.5296/jmr.v13i4.18883 }\end{aligned}$

\begin{abstract}
Leaders have a significant role in teams and groups, as they affect employee performance, motivation, and productivity. Given the significant position that leaders occupy in teams and group projects, this paper argues that it is important to simultaneously examine how trust in a leader, team interactions, and team performance interact with each other. Specifically, we formulated three hypotheses: First, we predicted a positive relationship between the level of trust that team members have in their team leader and the level of team performance; second, we predicted a positive relationship between the level of trust in a leader and the level of team interactions; last, we predicted that increased trust in a leader will increase team interactions and team performance. To test the model, we utilized data from $112 \mathrm{MBA}$
\end{abstract}




\section{Macrothink}

Journal of Management Research

ISSN 1941-899X

2021, Vol. 13, No. 4

students engaged in a web-based simulation game wherein students develop and execute the strategies for manufacturing and distributing a product. We used structural equation modeling to test these hypotheses. Our results support the importance and value of leader trust in team interactions. The results also indicate that team interaction positively influences team performance. However, they do not support our hypothesis that trust in a leader will positively influence team performance.

Keywords: trust, leadership, team interactions, team-based project, team performance 


\section{Introduction}

Leadership is a critical component for a group environment (Thite, 2000). The behaviors of leaders can enhance or impede team performance (Aronson, Reilly \& Lynn, 2006; Barczak \& Wilemon, 1991; Brown \& Eisenhardt, 1995). For example, leaders who promote knowledge sharing and build trust contribute to the team's overall effectiveness (Lee, Gillespie, Mann, \& Wearing, 2010). Team behavior and performance also can have strong implications for leadership (Aronson et al., 2006; Hoegl, Parboteeah, \& Gemuenden, 2003; Jassawalla \& Saahittal, 1999; Moenaert \& Souder, 1990). With the expansion of various forms of teamwork, the study of trust in work teams has gained momentum, particularly trust in team leaders (Lee et al., 2010; Mayer, Davis, Davis, \& Schoorman, 1995; Schaubroeck, Peng, \& Lam, 2011).

Understanding team performance is imperative in organizational, as well as higher education, settings. Educators have noted increased use of teams to build skills among university students and prepare them for experiences they will likely face in business settings (Werner \& Lester, 2001). According to a 2009 Hart Research Associates survey of U.S. businesses for the Association of American Colleges and Universities, 71\% of businesses had appealed to higher education institutions to develop teamwork skills among their students. Student team projects have long been used in collegiate business schools, and the literature offers considerable research about building teamwork skills. However, empirical evaluations that measure student teamwork and leadership skills, especially regarding trust in leaders, remain scant.

To examine the relationships between teamwork and leadership skills, we utilized sophisticated simulations that require students to work as a team. These simulations allowed us to investigate leader trust, team interactions, and team performance simultaneously. Specifically, we examined three questions. First, does trust in team leaders increase overall team performance? Second, does an increase in team interactions increase team performance? Third, does trust in team leaders and increased team interactions improve overall team performance? In the following, we review the literature, conceptual model, and research hypotheses, followed by a discussion of the method and results of our study, and then we conclude.

Much of the research on leadership has focused on the importance of leader style (Thite, 2000), leader personality (Aronson et al., 2006), and the role of inspiration in the leadership process (Joshi, Lazarova, \& Liao, 2008). The literature strongly supports the idea that firms should acquire and utilize talented leaders who create value and advantages in their teams and thus improve firm performance. For example, Thite (2000) recommends that leaders engage in a flexible style characterized by certain behaviors. These behaviors include promoting positive changes at the management level. Another study looked at the importance of leaders who can cultivate socialized relationships that promote team effectiveness (Joshi et al., 2008). These leaders actively engage with their teams to provide a "clear set of values [and] a means of expressing these values within the framework of collective action" (Howell \& Shamir, 2005, p. 98). 


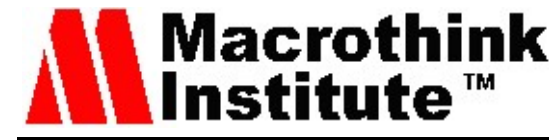

Teamwork involves high interdependency among members, in part because team members depend on each other in "various ways to accomplish their personal and organizational goals" (Mayer et al., 1995, p. 710). The literature thus underscores the importance of a particular leadership component: the team's trust in its leader. This trust can be defined as "the willingness of a party to be vulnerable to the actions of another party based on the expectation that the other will perform a particular action important to the trustor, irrespective of the ability to monitor or control that other party" (Mayer et al., 1995: 712). Trust is especially relevant in environments of high interdependence, close cooperation, and high flexibility (Salas, Sims, \& Burke, 2005). Moreover, trust in the team leader can directly influence knowledge sharing within the team (Dirks \& Ferrin, 2001; Mayer et al., 1995) and team performance (Lee et al., 2010). Therefore, trust is vital for the effective functioning of team relationships. We examine the level of trust that team members have in their team leader to assess team performance, interactions, and performance. Figure 1 shows our conceptual model.

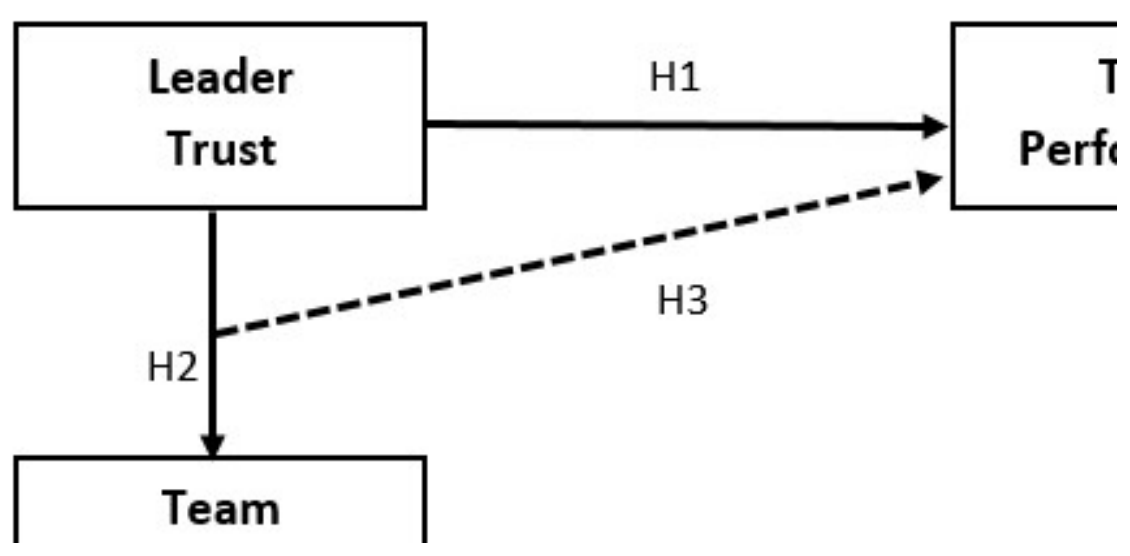

Figure 1. Conceptual framework

\subsection{Leader Trust and Team Performance}

In a study about the structure and measurement of trust in project teams, Gillespie (2003) identified two principal dimensions of trust in team contexts: the first is reliance, or the willingness to depend on others, and the second is disclosure of sensitive information, both personal and work-related. Zand (1972) identified accepting influence and sharing information as behavioral expressions of trust. Considering the importance of trust for productive and constructive teamwork, the literature has focused on defining trust in terms of the leader. For example, Mayer et al. (1995) found that perceptions of competence, benevolence, and integrity are key determinants of trust in a leader. Lee et al. (2010) found that leaders can earn the trust of their teams by engaging in timely knowledge building and providing technical expertise and advice. These practices demonstrate the leader's value and competence, thus increasing the team's willingness to rely on and trust the leader's professional knowledge, skills, and judgements. 
Leadership has vital impacts on the team and its overall output. In particular, several behaviors of the team leaders have been found to relate to the success of the team. First, such leaders are highly effective in obtaining resources, such as personnel and resources, which keep teams motivated and focused. Team leaders also facilitate cooperation within their teams (Aronson et al., 2006). Moreover, these leaders often are central to the value creation of the overall product concept, and they effectively communicate that message to team members (Atuahene-Gima, 2003; Brown \& Eisenhardt, 1995; Sheremata, 2000). The leader's effectiveness will affect team success and critically affect the performance of the team project. Thus, we predict the following:

Hypothesis 1: There will be a positive relationship between the level of trust that team members have in their team leader and the level of team performance.

\subsection{Leader Trust and Team Interactions}

Effective leaders manage their teams well (Aronson et al., 2006). Successful management includes coordinating and facilitating members' efforts (Barczak \& Wilemon, 2001), as well as promoting information sharing, coordination, and participation (Aronson et al., 2006). Although prior research finds a positive impact of team interaction on group performance (e.g., Mark, et al, 2000), no study has incorporated the role of leader trust on team interaction and the joint impact of both on performance. Collaborative behaviors rarely emerge in project teams unless team leaders create an environment of trust, creativity, and collaboration (Jassawalla \& Saahittal, 2002). In addition to creating an environment conducive to teamwork, the project leader unifies the efforts of the project team (Aronson et al., 2006). In this role of integrator, the leader motivates the team toward collective action (Atuahene-Gima, 2003; Badawy, 1995; Sheremata, 2000), while also coordinating and solving problems among and between team members and other functional groups (Clark \& Fujimoto, 1990; 1991). Ultimately, a leader should encourage attentiveness among team members and stimulate them to work together toward a unified goal. In this way, the leader affects both the team process and success of a project. Thus, we predict the following:

Hypothesis 2: There will be a positive relationship between the level of trust that team members have in their leader and the level of interactions within the team.

\subsection{Leader Trust, Team Interactions, and Team Performance}

Knowledge sharing is the exchange of knowledge, both tacit and explicit, that is relevant to the tasks of the team (Lee et al., 2010). It includes delivery and acceptance of technical information, skills, and expertise (Hansen \& Hass, 2007). Knowledge sharing can lead to superior team performance (Srivastava, Bartol, \& Locke, 2006), but it requires interaction and communication among team members (Cohen \& Bailey, 1997). Specifically, team members must coordinate their expertise about who knows what in the group (Faraj \& Sproull, 2000).

The literature discusses how trust reinforces a disposition to communicate with others, which is necessary for sharing knowledge (Mooradian, Renzl, \& Matzler, 2006). Such trust is related to openness and accuracy of information and knowledge shared (Zand, 1972). Lee et 
al. (2010) show that leaders can enhance their teams' willingness to rely on and disclose information to the team by building expertise within the team and that this knowledge sharing significantly predicts leaders' and managers' ratings of team performance. In this way, team leaders who build trust encourage knowledge sharing and improve team effectiveness. Several studies view the leader as a pivotal figure with critical influence over project success (Aronson et al., 2006; Atuahene-Gima, 2003; Barczak \& Wilemon, 2001; Brown \& Eisenhardt, 1995; Sheremata, 2000). This influence stems in part from the ability of effective team leaders to maintain the motivation and focus of their teams (Aronson et al., 2006). We therefore predict the following:

Hypothesis 3: As the level of trust in a team leader increases, team interactions also will increase, leading to increased team performance.

\section{Method}

\subsection{Simulation Computer Game}

The web-based Supply Chain Game from Responsive Learning Technologies (http://responsive.net/supply.html) allows students to manage a supply chain network for a virtual chemical company called Jacobs. Although not intended to teach leadership or teamwork, the simulation provides a rich platform for observing different aspects of both. The game consists of two successive exercises: "oneregion" and "network." The oneregion exercise focuses on forecasting and inventory management techniques to balance demand fulfillment and costs. The subsequent network exercise emphasizes planning and optimizing logistics networks for demand fulfillment in new markets. Decisions involve mapping logistics and distributions networks, building additional factories or warehouses, recalculating inventory, and strategizing new markets to maximize profit.

We used a self-selection approach to assign students to teams of three or four members each. Each team formulated efficient operations strategies to meet capacity, production, inventory, and transportation needs and avoid a stock out. They also determined if the capacity of one factory and one warehouse in one region were sufficient to meet demand in new markets. If the team added factories and warehouses, they had to determine how many to add, as well as their optimal capacities, locations, and inventory schedules. Students had to design optimal fulfillment routes by determining which warehouse(s) should serve which customers to maximize profits. Throughout the simulation, students could change parameters and establish fulfillment routes under the factory and warehouse menus to achieve their goals, but only when inventory was insufficient to fulfill incoming demand. The objective for both exercises was to maximize profit at the end of the simulation, which was designed to be completed within a 2-hour class period. Profits from the second exercise determined each team's standing.

\subsection{Survey Development}

Our research purpose was to gather inputs about the relationship between trust, team interactions, and team performance. To this end, we developed a two-part survey to be distributed to participants who completed the supply chain management simulation game. 


\section{$\triangle$ Macrothink}

The first part assessed the student's trust in the simulation team leader. The second part assessed the student's interactions with other team members. Table 1 lists the variables for leader trust and team interaction.

Table I. Variables determined by literature review

\begin{tabular}{|l|l|}
\hline \multicolumn{1}{|c|}{ Variables for Leadership and Team Interactions } & \multicolumn{1}{|c|}{ Variable Name } \\
\hline LEADERSHIP & \\
\hline Level of confidence and trust in leadership style & Leadership Style \\
\hline Level of confidence and trust in leader's knowledge & Leader-related Knowledge \\
\hline $\begin{array}{l}\text { Level of confidence and trust in leader's related } \\
\text { experience }\end{array}$ & Leader-related Experience \\
\hline TEAM INTERACTIONS & Team Ground Rules \\
\hline Established ground rules & Open Discussion \\
\hline $\begin{array}{l}\text { Discussed problems openly and worked together to } \\
\text { resolve }\end{array}$ & Share Information \\
\hline Willingly shared information & Equal Contribution \\
\hline All team members contributed equally to the work & Cooperation \\
\hline All team members cooperated to get the work done & \\
\hline
\end{tabular}

\subsection{Participants}

Participants included 112 MBA students enrolled in a core-required course at a Hong Kong University China MBA program from July 2017 to July 2019. The program was accredited by the Association to Advance Collegiate Schools of Business. Of the 112 participants, 23 indicated that no leader was involved in the team, and 4 respondents did not respond to this survey question. Hence, 85 cases were initially retained, of which 4 had missing data on leader perception (i.e., knowledge, leadership style, experience). Because the missing cases seemed to appear randomly, we deleted the missing cases. The final sample size thus comprised 81 cases for data analysis. Table 2 shows the biographical information about the participants, including gender, age, and years of working experience, which were incorporated in the model as control variables. 


\section{Al Macrothink}

Table 2. Biographical information about the research participants

\begin{tabular}{|c|c|c|c|c|c|}
\hline \multicolumn{2}{|c|}{ Gender } & \multicolumn{2}{c|}{ Age } & Working Experience \\
\hline Females & $47 \%$ & $<26$ & $16 \%$ & $<5$ & $15 \%$ \\
\hline Male & $53 \%$ & $26-30$ & $10 \%$ & $6-10$ & $26 \%$ \\
\hline & & $31-35$ & $31 \%$ & $11-15$ & $31 \%$ \\
\hline & & $36-40$ & $35 \%$ & $16-20$ & $24 \%$ \\
\hline & & $41-45$ & $4 \%$ & $>20$ & $4 \%$ \\
\hline & & $>45$ & $4 \%$ & & \\
\hline
\end{tabular}

\section{Results}

We used a 5-point Likert-type scale, ranging from 1 (strongly disagree) to 5 (strongly agree), to measure each survey item. The following five items, adapted from previous studies, measured team interaction: (1) "My team took time to establish some ground rules and processes for the simulation" (Tiffen, 2014); (2) "When confronted with a problem, team members discussed it openly and tried to resolve it together" (Tjosvold, 1988); (3) "Members of my team were very willing to share information with other;" (Campion, Medsker, \& Higgs, 1993); (4) "Nearly all the members on my team contributed equally to the work;" (Campion, Medsker, \& Higgs, 1993); and (5) "Members of my team cooperated to get the work done" (Campion, Medsker, \& Higgs, 1993).

Moreover, we included trust in leadership style, leader knowledge (Lee et al., 2010), and work experience (Hughes \& Jones, 2011) as the three indicators to reflect leader trust. The three survey items for leader trust were: (1) "I have confidence and trust in my team leader regarding his/her operations management experience" (Hughes \& Jones, 2011), (2) "I have confidence and trust in my team leader regarding his/her knowledge," (Lee et al., 2010); and (3) "I have confidence and trust in my team leader regarding his/her leadership style" (Lee et al., 2010). 


\section{Macrothink}

Journal of Management Research

ISSN 1941-899X 2021, Vol. 13, No. 4

Table 3. Descriptive statistics and variable correlations between leadership and team interactions

\begin{tabular}{|c|c|c|c|c|c|c|c|c|c|c|c|c|c|}
\hline & Variable & Mean & SD & 1 & 2 & 3 & 4 & 5 & 6 & 7 & 8 & 9 & 10 \\
\hline 1 & Leader Related Experience & 4.47 & .57 & 1 & & & & & & & & & \\
\hline 2 & Leader Related knowledge & 4.46 & .57 & $.752^{* *}$ & 1 & & & & & & & & \\
\hline 3 & Leadership Style & 4.43 & .57 & $.714^{* *}$ & $.693^{* *}$ & 1 & & & & & & & \\
\hline 4 & Consider All Inputs & 4.48 & .59 & $.394^{* *}$ & $.375^{* *}$ & $.524^{* *}$ & 1 & & & & & & \\
\hline 5 & Solo Decision & 2.91 & 10.85 & -.100 & -.094 & -.099 & -.121 & 1 & & & & & \\
\hline 6 & Team Ground Rules & 4.43 & .63 & .193 & .139 & $.239^{*}$ & $.472^{* *}$ & -.104 & 1 & & & & \\
\hline 7 & Open Discussion & 4.47 & .67 & .136 & .086 & .215 & $.523^{* *}$ & -.106 & $.636^{* *}$ & 1 & & & \\
\hline 8 & Share Information & 4.57 & .67 & .112 & .098 & $.267^{*}$ & $.404^{* *}$ & -.115 & $.447^{* *}$ & $.484^{* *}$ & 1 & & \\
\hline 9 & Equal Contribution & 3.98 & 1.01 & .107 & .193 & .127 & .103 & -.010 & $.291^{* *}$ & $.366^{* *}$ & $.298^{* *}$ & 1 & \\
\hline 10 & Cooperation & 4.60 & .52 & .170 & .196 & $.248^{*}$ & $.628^{* *}$ & -.162 & $.568^{* *}$ & $.648^{* *}$ & $.476^{* *}$ & $.340^{* *}$ & 1 \\
\hline
\end{tabular}

Table 3 reports the means, standard deviations, and intercorrelations of the study.

Table 4. Variable correlations for team members' level of trust in leadership and simulation performance

\begin{tabular}{llllll}
\hline & & 1 & 2 & 3 & 4 \\
\hline 1 & Leader-related Experience & 1 & & & \\
2 & Leader-related Knowledge & $.752^{* *}$ & 1 & & \\
3 & Leadership Style & $.714^{* *}$ & $.693 * *$ & 1 & \\
4 & Simulation Performance & 0.082 & 0.052 & 0.049 & 1 \\
\hline
\end{tabular}

Table 4 shows the correlation between team members' trust in their leader and the team's performance in the simulation. The results show no relationship between simulation performance and any of the three leader trust items. 


\section{Macrothink}

Journal of Management Research

ISSN 1941-899X

2021, Vol. 13, No. 4

Table 5. Variable correlations for team interactions and simulation performance $(\mathrm{N}=81)$

\begin{tabular}{|c|c|c|c|c|c|c|c|}
\hline & & 1 & 2 & 3 & 4 & 5 & 6 \\
\hline 1 & Team Ground Rules & 1 & & & & & \\
\hline 2 & Open Discussion & $.636^{* *}$ & 1 & & & & \\
\hline 3 & Share Information & $.447^{* *}$ & $.484^{* *}$ & 1 & & & \\
\hline 4 & Equal Contribution & $.291^{* *}$ & $.366^{* *}$ & $.298^{* *}$ & 1 & & \\
\hline 5 & Cooperation & $.568^{* *}$ & $.648^{* *}$ & $.476^{* *}$ & $.340^{* *}$ & 1 & \\
\hline 6 & Simulation Performance & $.272^{*}$ & $.243^{*}$ & $.285^{* *}$ & -0.062 & 0.104 & 1 \\
\hline
\end{tabular}

Table 5 shows a correlation between the results for team cooperation (i.e., "Discussed problems openly and worked together to resolve" and "Members of my team were very willing to share information with others").

Structural equation modeling uses a two-step procedure (Anderson \& Gerbing, 1988). The measurement model is investigated prior to the simultaneous estimation of measurement and structural models. Hence, we first run a factor model with only the measured variables of leader trust and team interaction before estimating the full structural model. An exploratory factor analysis was executed using the maximum likelihood extraction method, with varimax rotation for both leader trust and team interaction. Only one factor was extracted for each construct. Cronbach's alpha was .77 for team interaction and .88 for the leader trust construct, indicating that both scales achieve internal consistency. The variance extracted was $48.87 \%$ for team interaction and $71.85 \%$ for leader trust. 
Table 6. Results of measurement model

\begin{tabular}{|c|c|c|c|c|}
\hline Paths $^{a}$ & & Construct & $\begin{array}{l}\text { Standardized } \\
\text { Regression Weights }\end{array}$ & p values \\
\hline Leadership Style & $<--$ & Leadertrust & $0.82^{\mathrm{b}}$ & \\
\hline Leader Related Knowledge & $<--$ & Leadertrust & 0.85 & $* * *$ \\
\hline Leader Related Experience & $<--$ & Leadertrust & 0.88 & $* * *$ \\
\hline Equal Contribution & $<--$ & Teaminteraction & $0.44^{\mathrm{b}}$ & \\
\hline Share Information & $<--$ & Teaminteraction & 0.6 & $* * *$ \\
\hline Open Discussion & $<--$ & Teaminteraction & 0.83 & $* * *$ \\
\hline Team Groundrules & $<--$ & Teaminteraction & 0.75 & $* * *$ \\
\hline Cooperation & $<--$ & Teaminteraction & 0.78 & $* * *$ \\
\hline \multicolumn{5}{|c|}{ a. Goodness of fit statistics $\chi_{,}^{2}(19)=12.4, \mathrm{CFI}=1, \mathrm{GFI}=.96, \mathrm{AGFI}=.93, \quad \mathrm{RMSEA}=0$} \\
\hline \multicolumn{5}{|l|}{ b. fixed parameter } \\
\hline$* * *: p<.001$ & & & & \\
\hline
\end{tabular}

We then estimated a factor model with all indicators of the two latent constructs using confirmatory factor analyses. According to Table 6, all item loadings on their corresponding construct were significant at $p<.05$, demonstrating adequate convergent validity. For this measurement model consisting of leader trust and team interaction, the goodness-of-fit, adjusted goodness-of-fit, root-mean-square error of approximation, and comparative fit index were $.96, .93, .0$, and .1 , respectively, indicating an adequate model fit.

We included gender, age, and years of working experience in the structural model as control variables. Leader trust, team interaction, and simulation performance were the main constructs whose relationship was assessed. Figure 2 shows the constructs and paths in the structural equation model. 


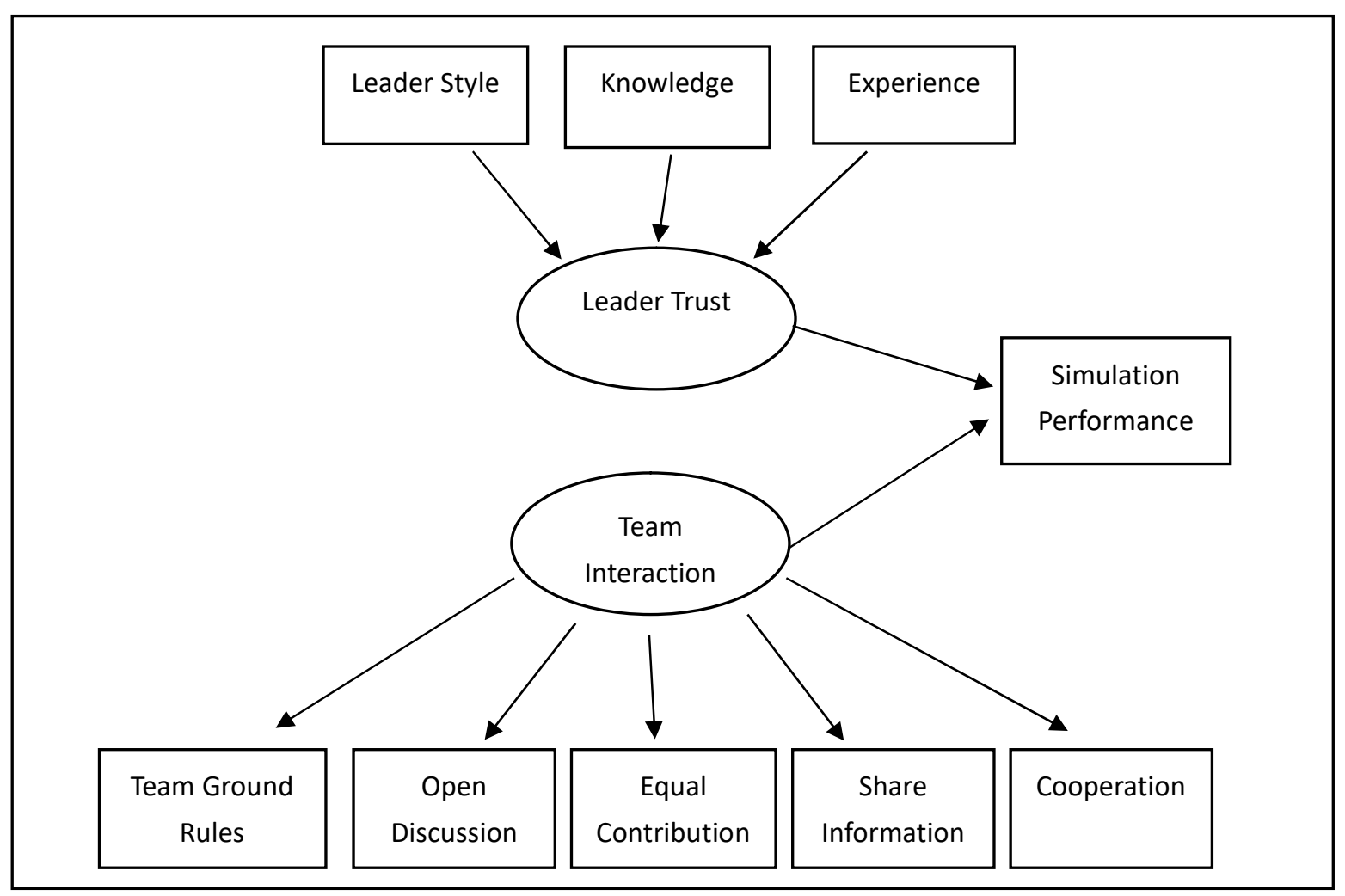

Figure 2. Constructs and Paths in the Structural Equation Model

Table 7. Parameter estimates for paths

\begin{tabular}{|c|l|c|c|}
\hline Hypotheses & \multicolumn{1}{|c|}{ Paths } & $\begin{array}{c}\text { Standardized } \\
\text { Parameter Estimates }\end{array}$ & $\boldsymbol{p}$ values \\
\hline $\mathrm{H}_{1}$ & Performance $<---$ Leader trust & -0.01 & 0.96 \\
\hline $\mathrm{H}_{2}$ & Team interaction $<---$ Leader trust & 0.27 & $* *$ \\
\hline $\mathrm{H}_{3}$ & Performance $<---$ Team interaction & 0.28 & $* *$ \\
\hline a. Goodness of fit statistics $\chi, 2(56) 2=61.44, \mathrm{CFI}=.98, \mathrm{GFI}=.90, \mathrm{AGFI}=.84, \mathrm{RMSEA}=0.04$ \\
\hline$* * p<.05$
\end{tabular}

The effect of the control variables is minimal. Except for the fact that male (vs. female) leaders have a negative impact on team interaction (loading=-.25, $<<.05$ ), the rest of the control variables do not have any significant impact on leader trust and team interaction $(p>.05)$. To test the structural relationships, the hypothesized paths were estimated. Hypothesis 2 and Hypothesis 3 were supported. The overall fit of the model thus is acceptable, 
because the goodness-of-fit statistics ( $\mathrm{CFI}=.98$, GFI=.90, AGFI=.84, RMSEA=.04) are satisfactory. Table 7 reports the results.

Hypothesis 1 predicts that the trust team members have in the leader will positively influence team performance. This hypothesis was not supported $(p>.05)$. However, the results do provide support for Hypothesis 2, which predict that leader trust will positively impact team interactions (loading=.27, $p<.05$ ). This finding is consistent with prior discovery that higher trust in leaders will foster more open communication among team members (Lee et al., 2010). Last, our finding supports Hypothesis 3, which predicts that team interaction will positively influence team performance (loading=.28, $\mathrm{p}<.05$ ). This corresponds with previous finding that coaching students on team interaction prior to team work effectively improves team interaction (Marks et al., 2000).

\section{Discussion}

The goal of this study was to simultaneously examine a team setting and evaluate the relationships between trust in leadership, team interaction, and performance. We assessed these relationships by observing how college students participate in a collaborative, computer-based simulation game. We were specifically interested in the relationship between leader trust and team interaction. Our findings demonstrated that leader trust had a positive impact on team interaction and that team interaction influenced team performance positively. However, the results did not support Hypothesis 1 that the trust team members have in the leader will positively influence team performance

\subsection{Leader trust and team performance}

We included team leaders' knowledge, experience, and style in the leader trust scale in our study. Multiple plausible explanations can explain the result. First, the computer simulation game used in this study required a strong grasp of operations and supply chain management, including knowledge of quantitative techniques, forecasting, inventory management, logistics, and financial calculation. Based on an informal survey that is conducted at the beginning of each class term, very few of the students in our sample had worked in either operations or supply chain management. It would have been challenging for these students to apply intricate concepts and quantitative techniques in the short time frame of our study.

Second, 55\% of participants had over 10 years of working experience, which could have interfered with their decisions during the simulation game. Web-based experiential learning simulation games can be powerful education tools, because they effectively link classroom concepts with realistic problem-solving scenarios (Miyaoka, 2005; Singh, Mangalaraj, \& Taneja 2010). However, the purpose of these games is to reinforce classroom concepts and as such, they may not accurately represent the dynamics of their business environment. We observed that experienced participants often naturally became the team leaders. However, these leaders may have unnecessarily complicated the simulation scenarios due to complexities they have encountered in the real world through personal experiences. In turn, team members would further rely on the experienced leader's decisions, even if that experience did not directly relate to the simulation. 
Third, when designing the questionnaire for this study, we did not specify the type of leader styles. Instead, we focused on whether leaders could motivate their teams to achieve the goal. We found that even effective leaders struggled to win the simulation if their teams did not have the appropriate problem-solving skills. It is worth noting here that all simulation teams were formed by self-selection, which may have aided in the initial cohesion of the team but also may have contributed to a lack of adequate critical skills (Mello, 1993; Strong \& Anderson, 1990).

Fourth, we found that trust in the leader was a more complex concept than initially anticipated. There are two possible reasons for this complexity. Trusting a leader may be too unilateral to foster good performance, and it may not be sufficient to lead to good performance if that trust is built on new knowledge or length of working experience. A team's trust in its leader also does not guarantee that the leader trusts team members back. Without mutual trust between the leader and team members, performance may not improve.

\subsection{Leader trust and team interactions}

Although trust in the leader did not directly lead to better team performance, our results showed that it improved team interaction. Teams with clear ground rules set by leaders at the beginning of the simulation usually achieved superior outcomes. As shown in Table 2, trust in the leader was significantly correlated to the establishment of ground rules for achieving the goal. The variable correlations also demonstrated that trust in the leader promoted the sharing of information and cooperation among team members.

Moreover, effective team interaction and teamwork behavior can significantly influence trust among team members in both traditional and virtual teams. Constructing positive interpersonal relationships takes time (Bligh, Pearce, \& Kohles, 2006; Powell, Galvin, \& Piccoli, 2006; Sheng, Tian, \& Chen, 2010). When students formed their simulation teams at the beginning of the semester, they were not familiar or sociable with each other. However, after the first practice exercise, regardless of the outcomes, trust among team members increased, which in turn increased team cooperation. Although our study did not test how trust in the leader enhanced trust among team members, we suspect that a high level of trust in the leader was an important factor.

\subsection{Leader trust, team interactions, and team performance}

Our findings indicate that when trust in the leader and team interaction both increased, team performance improved. In addition, interaction variables (e.g., "Discussed problems openly and worked together to resolve," "Willingly shared information," and "All team members cooperated to get the work done") were significantly correlated with team performance (see Table 4). We also found a high probability of profit increase among those teams ranked at the bottom for the first simulation exercise. We observed that some of these team leaders reformed team strategies and modified team members' roles and responsibilities for the second exercise. Team members followed their leader's instructions, and they expressed and discussed their thoughts more openly. As a result, cooperation within the team then increased. 


\section{Limitations and future research opportunities}

There are some limitations to the findings in this research. First, in our study, $75 \%$ of team members indicated that their team leaders either naturally became or volunteered to serve as a leader. It is worth noting that the leaders accepted by their teams were based on cognitive-based trust or affective-based trust (Lewis \& Weigert, 1985). Cognitive-based trust is based on what people consider as being evidence of trustworthiness, they choose whom to trust in which respects and under which circumstances, (Lewis \& Weigert, 1985). Evidence of trustworthiness, such as available knowledge, experience, reliability, and dependability (Luhmann, 1979). Affective-based trust consists of emotional bonds between individuals (Lewis \& Weigert, 1985).

Second, when designing the questionnaire for this study, we did not specify the trustor and trustee characteristics in the leader trust category (Costa, Fulmer, \& Anderson, 2017). Instead, we focused on whether leaders could motivate their teams to achieve the goal. People trust others differently due to different life experiences, personality types, cultural backgrounds, education, and several other socioeconomic factors (Mayer et al., 1995). Cross-cultural research has also shown that propensity to trust varies greatly from country to country (Delhey \& Newton, 2005). Individual propensity to trust in collectivistic societies has been shown lower level than in individualistic societies (Huff \& Kelley, 2003). Our research was conducted in a single country of China. Although we believe our findings have global implications, we recognize this is a limitation. We also believe this is an opportunity for future research on cross-cultural differences by observing teams in other cultural settings in various countries. Moreover, we believe using the dimensions of cultural values developed by Hofstede (1984; 2001) (i.e., power distance, individualism/collectivism, masculinity/femininity, uncertainty avoidance) would be useful for future research.

\section{Conclusion}

In conclusion, this paper aims to stimulate the conversation around trust in a leader, team interactions, and team performance and the interaction with each other. Students learn more about course materials when they have good team experiences. Self-selected teams enhance these good experiences (Bacon, Stewart, \& Sliver, 1999). As educators emphasize team-based learning in the classroom, we believe it is important to understand how to facilitate teamwork success by increasing the trust between team leader and members.

The empirical evidence in this study shows that a team's trust in its leader was not positively linked to team performance. In other words, trusting a leader's knowledge, working experience, and style does not ensure good team performance. Other factors, such as understanding the course material, appropriate problem-solving skills, and mutual trust between leader and team members also affect team performance. Therefore, this paper suggests that educators explain these required critical skills when students select their team members in order to improve performance.

Ultimately, our findings show that trust in the leader has a positive relationship with team interactions, which is also positively linked to team performance. Variables in team 
interactions, such as establishing ground rules, sharing information within the team, and cooperating with team members, are significantly correlated with the level of trust in leadership. Through greater understanding, an effective leader can leverage these variables to help achieve the team's goals, which in turn can lead to better performance.

\section{References}

Anderson, J. C., \& Gerbing, D. W. (1988). Structural equation modeling in practice: A review and recommended two-step approach. Psychological bulletin, 103(3), 411. https://doi.org/10.1037/0033-2909.103.3.411

Aronson, Z., Reilly, R., \& Lynn, G. (2006). The impact of leader personality on new product development teamwork and performance: The moderating role of uncertainty. Journal of Engineering and Technology Management, 23, 221-247. https://doi.org/10.1016/j.jengtecman.2006.06.003

Atuahene-Gima, K. (2003). The effects of centrifugal and centripetal forces on product development speed and quality: How does problem solving matter? Academy of Management, 46(3), 359-373. https://doi.org/10.2307/30040629

Bacon, D., Stewart, K., \& Silver, W. (1999). Lessons from the best and worst student team experiences: How a teacher can make the difference. Journal of Management Education, 23(5), 467-488. https://doi.org/10.1177/105256299902300503

Badawy, M. (1995). Developing managerial skills in engineers and scientists. New York, NY: Wiley.

Barczak, G., \& Wilemon, D. (1991). Communication patterns of new product development team leaders. IEEE Transactions on Engineering Management, 38(2), 101-109. https://doi.org/10.1109/17.78406

Barczak, G., \& Wilemon, D. (2001). Factors influencing product development team satisfaction. European Journal of Innovation Management, 4(1), 32-43. https://doi.org/10.1108/14601060110365556

Bligh, M., Pearce, C. L., \& Kohles, J. C. (2006). The importance of self- and shared leadership in team based knowledge work: A meso-level model of leadership dynamics. Journal of Managerial Psychology, 21, 296-318. https://doi.org/10.1108/02683940610663105

Brown, S., \& Eisenhardt, K. (1995). Product development: Past research, present findings and future research. Academy of Management Review, 20(2), 343-378. https://doi.org/10.5465/amr.1995.9507312922

Campion, M. A., Medsker, G. J., \& Higgs, A. C. (1993). Relations between work group characteristics and effectiveness: Implications for designing effective work groups. Personnel Psychology, 46(4), 823-847. https://doi.org/10.1111/j.1744-6570.1993.tb01571.x 


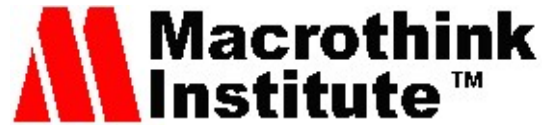

Journal of Management Research

ISSN 1941-899X

2021, Vol. 13, No. 4

Cohen, S., \& Bailey, D. (1997). What makes team work: Group effectiveness research from the shop floor to the executive suite. Journal of Management, 23(3), 239-90. https://doi.org/10.1177/014920639702300303

Costa, A, Fulmer, C., \& Anderson, N., (2017). Trust in work teams: An integrative review, multilevel model, and future directions. Journal of Organizational Behavior, 39(2), 169-184. https://doi.org/10.1002/job.2213

Delhey, J., Newton, K. (2005). Predicting cross-national levels of social trust: Global pattern or Nordic exceptionalism? European Sociological Review, 21(4), 311-327, https://doi.org/10.1093/esr/jci022

Dirks, K., \& Ferrin, D. (2001). The role of trust in organizational settings. Organization Science, 12(4), 450-467. https://doi.org/10.1287/orsc.12.4.450.10640

Faraj, S., \& Sproull, L. (2000). Coordinating expertise in software development teams. Management Science, 46(12), 1554-1568. https://doi.org/10.1287/mnsc.46.12.1554.12072

Gillespie, N. (2003). Measuring trust in work relationships: The behavioural trust inventory, Paper presented at the Academy of Management Annual Meeting, Seattle, WA, USA, 1-6 August.

Hansen, M., \& Haas, M. (2007). Different knowledge, different benefits: Toward a productivity perspective on knowledge sharing in organizations. Strategic Management Journal, 28(11), 33-53. https://doi.org/10.1002/smj.631

Hart Research Associates. (2009). Raising the bar: Employers' views on college learning in the wake of the economic downturn. Washington, DC: Hart Research Associates.

Hofstede, G. (1984). Culture's consequences: International differences in work-related values. Beverly Hills, California: Sage.

Hofstede, G. (2001). Culture's consequences: Comparing values, behaviors, institutions, and organizations across nations. Thousand Oaks, California: Sage.

Hoegl, M., Parboteeah, K., \& Gemuenden, H. (2003). When teamwork really matters: Task innovativeness as a moderator of the teamwork-performance relationship in software development projects. Journal of Engineering and Technology Management, 20(4), 281-302. https://doi.org/10.1016/j.jengtecman.2003.08.001

Howell, J., \& Shamir, B. (2005). The role of followers in the charismatic leadership process: Relationships and their consequences. The Academy of Management Review, 30(1), 96-112. https://doi.org/10.5465/amr.2005.15281435

Huff, L., \& Kelley, L (2003). Levels of organizational trust in individualist versus collectivist societies: A seven-nation study. Organization Science, 14(1). https://doi.org/10.1287/orsc.14.1.81.12807 
Jassawalla, A., \& Saahittal, H. (1999). Building collaborative cross-functional new product teams. Academy of Management Executive, 13(3), 50-61. https://doi.org/10.5465/ame.1999.2210314

Jassawalla, A., \& Saahittal, H. (2002). The role of senior management and team leaders in building collaborative new product development teams. Engineering Management Journal, 13(2), 33-39. https://doi.org/10.1080/10429247.2001.11415114

Joshi, A., Lazarova, B., \& Liao, H. (2008). Getting everyone on board: The role of inspirational leadership in geographically dispersed teams. Organization Science, 20(1), 240-252. https://doi.org/10.1287/orsc.1080.0383

Lee, P., Gillespie, N., Mann, L., \& Wearing, A. (2010). Leadership and trust: Their effect on knowledge sharing and team performance. Management Learning, 41(4), 473-491. https://doi.org/10.1177/1350507610362036

Lewis, J. D., \& Weigert, A. (1985). Trust as a social reality. Social forces, 63(4), 967-985, https://doi.org/10.1093/sf/63.4.967

Luhmann, N. (1979). Trust and power. Chichester: Wiley.

Marks, M. A., Zaccaro, S. J., \& Mathieu, J. E. (2000). Performance implications of leader briefings and team-interaction training for team adaptation to novel environments. Journal of Applied Psychology, 85(6), 971-986. https://doi.org/10.1037/0021-9010.85.6.971

Mayer, R., Davis, R., Davis, J., \& Schoorman, F. (1995). An integrative model of organizational trust, The Academy of Management Review, 20(3), 709-734. https://doi.org/10.5465/amr.1995.9508080335

McCleskey, JA., (2014). Situational, transformational, and transactional leadership and leadership development, Journal of Business Studies Quarterly, 5(4), 117-130.

Mello, J. (1993). Improving individual member accountability in small work group settings. $\begin{array}{llr}\text { Journal of } \quad \text { Management } & \text { Education, 253-259. }\end{array}$ https://doi.org/10.1177/105256299301700210

Miyaoka, J. (2005). Making operations management fun: Littlefield Technologies. INFORMS Transactions on Education, 5(2), 80-83. https://doi.org/10.1287/ited.5.2.80

Moenaert, R., \& Souder, W. (1990). An information transfer model for integrating marketing and R\&D personnel in new product development projects. Journal of Product Innovation Management, 7(2), 91-107. https://doi.org/10.1111/1540-5885.720091

Mooradian, T., Renzl, B., \& Matzler, K. (2006). Who trusts? Personality, trust and knowledge sharing. Management Learning, 37(4), 523-40. https://doi.org/10.1177/1350507606073424

Powell, A., Galvin, J., \& Piccoli, G. (2006). Antecedents to team member commitment from near and far: A comparison between collocated and virtual teams. Information Technology and People, 19(4), 299-322. https://doi.org/10.1108/09593840610718018 


\section{Macrothink}

Journal of Management Research

ISSN 1941-899X

2021, Vol. 13, No. 4

Schaubroeck, J., Peng, A., \& Lam, S. (2011). Cognition-based and affect-based trust as mediators of leader behavior influences on team performance. Journal of Applied Psychology, 96(4), 863-871. https://doi.org/10.1037/a0022625

Sheng, C.W., Tian, Y.F., \& Chen, M. C. (2010). Relationship among teamwork behavior, trust, perceived team support, and team commitment. Social Behavior and Personality, 38(10), 1297-1306. https://doi.org/10.2224/sbp.2010.38.10.1297

Sheremata, W. (2000). Centrifugal and centripetal forces in radical new product development under time pressure. Academy of Management Review, 25, 389-408. https://doi.org/10.5465/amr.2000.3312925

Singh, A., Mangalaraj G., \& Taneja, A. (2010). Bolstering teaching through online tools. Journal of Information System Education, 21(3), 299-312.

Srivastava, A., Bartol, K., \& Locke, E. (2006). Empowering leadership in management teams: Effects on knowledge sharing, efficacy, and team performance. Academy of Management Journal, 49(6), 1239-51. https://doi.org/10.5465/amj.2006.23478718

Strong, J., \& Anderson, R. (1990). Free-riding in group projects: Control mechanisms and preliminary data. Journal of Marketing Education, 12(2), 61-67. https://doi.org/10.1177/027347539001200208

Thite, M. (2000). Leadership styles in information technology projects. International Journal of Project Management, 18(4), 235-241. https://doi.org/10.1016/S0263-7863(99)00021-6

Tjosvold, D. (1988). Cooperative and competitive dynamics within and between organizational units. Human Relations, 41(6), 425-436. https://doi.org/10.1177/001872678804100601

Werner, J., \& Lester, S. (2001). Applying a team effectiveness framework to the performance of student case teams. Human Resource Development Quarterly, 12(4), 385-402. https://doi.org/10.1002/hrdq.1004

Zand, D. (1972). Trust and managerial problem solving. Administrative Science Quarterly, 17(2), 229-39. https://doi.org/10.2307/2393957 